\title{
The Molecular Genetic Features of Patients with Juvenile Arthritis in Yakutia
}

\author{
Khariton A. Kurtanov, $\mathrm{PhD}^{1^{*}}$; Fekla V. Vinokurova ${ }^{1}$; Nadezhda I. Pavlova, $\mathrm{PhD}^{1}$; \\ Aitalina S. Golderova, $\mathrm{PhD}, \mathrm{ScD}^{2}$; Aleksandra T. Diakonova ${ }^{1}$; \\ Galina A. Apsolikhova ${ }^{1}$; Vlad A. Alekseev ${ }^{1}$ \\ ${ }^{1}$ Yakut Science Center of Complex Medical Problems \\ ${ }^{2}$ M. K. Ammosov North-Eastern Federal University Yakutsk, Russia \\ Yakutsk, the Republic of Sakha (Yakutia), Russia
}

\begin{abstract}
The research objective was to conduct a retrospective study of patients with Juvenile arthritis (JA) in association with the carriage of the HLA-B27 allele.

Materials and Methods: A total of 73 patients (39 boys and 34 girls aged from 1 to 16 years, mean age of 10.28 \pm 4.24 years) living in Yakutia with Juvenile Chronic Arthritis (JCA), Juvenile Ankylosing Spondylitis (JAS), Juvenile Psoriatic Arthritis (JPsA), and reactive arthritis (RA) were examined. Among them, 62(84.9\%) children were of Yakut nationality, and 11(15.1\%) the Russian nationality. The control group included 85 Yakuts without clinical diagnosis of arthritis. Testing for the HLA-B27 allele was performed according to Dominquez et al. (1992) as modified by Steffens-Nakken et al. (1995).

Results: According to the genotyping results, in 30 of 73 examined samples an association was found between the HLA-B27 allele carriage and JA. The HLA-B27 allele was diagnosed in 24 (38.7\%) Yakuts and 6 (54.5\%) ethnic Russians. For further analysis, all patients (Yakuts, Russians) were divided into diagnosis-related groups. Diagnoses of JAS ( $\mathrm{n}=10)$ and JCA ( $\mathrm{n}=9$ ) prevailed in Yakuts. In the Russian children, RA was more common $(\mathrm{n}=4)$. In population sampling of Yakuts, the frequency of the $H L A-B 27$ allele was $32.9 \%$. A comparison of the frequencies of the $H L A-B 27$ allele among the Yakut patient groups and the control group found a statistically significant association with JAS. The carriage of the $H L A-B 27$ allele in Yakut females did not increase the risk of JAS development, whereas in male Yakuts this risk increased by 5.6 times.(International Journal of Biomedicine. 2019;9(2):121-124.)
\end{abstract}

Key Words: Juvenile ankylosing spondylitis • HLA-B27 • Yakuts

\section{Introduction}

Juvenile arthritis (JA) is a group designation of the numbers of rheumatic children's diseases presented in ICD10, heading M.08 and M.09, including Juvenile Rheumatoid Arthritis (JRA), Juvenile Ankylosing Spondylitis (JAS), Juvenile Chronic Arthritis (JCA) not otherwise specified, Juvenile Psoriatic Arthritis (JPsA), and arthritis with inflammatory bowel diseases (Crohn's disease, Whipple's disease, non-specific enterocolitis).

*Corresponding author: Khariton A. Kurtanov, PhD. Yakut Science Center of Complex Medical Problems. Yakutsk, the Republic of Sakha (Yakutia),Russia.E-mail: hariton_kurtanov@mail.ru
JA is an umbrella term used to describe the many autoimmune and inflammatory conditions that can develop in children under the age of $16^{(1-3)}$ Characteristics associated with these conditions are familial susceptibility, existence of the pathogenetic or associated markers of the disease predisposition, the variability of clinical implications depending on gender and age, lower level of coincidence on a disease at monochorial twins, and others..$^{(4)}$

The human leukocyte antigen (HLA) class I molecule HLAB27 was the first genetic risk factor identified as associating with JAS and remains the most important risk locus for this archetypal spondyloarthropathy. ${ }^{(5)}$ The important role of $H L A-B 27$ in JA pathogenesis has been known for a long time. The number of the first immunogenic works revealed the 
upregulation of $H L A-B 27$ among children with JA. ${ }^{(6.7)}$

According to contemporary views, the basis of pathogenesis of immune inflammatory rheumatic diseases is the complex combination of genetically determined and acquired defects ("imbalance") of immune regulatory mechanisms, limiting pathological activation of the immune system in response to potentially pathogenic factors of the external environment. ${ }^{(8-11)}$ With rheumatic diseases, under the influence of the IL-23 excess production, the folding of a HLA-B27 heavy chain appears to be slower than other HLA-alleles, leading to misfolding. ${ }^{(12)}$ In the presence of endoplasmic reticulum stress there is an abnormal accumulation of misfolded heavy chains leading to activation not only of the unfolded protein response, but also of a nuclear factor of NF-kB - a key transcriptional regulator of synthesis of pro-inflammatory cytokines, including IL-17 and TNF $\alpha$, which also play an important role in the development of inflammation. There are data showing that an adjournment of $\beta 2 \mathrm{~m}$ caused by a high rate of dissociation between a $H L A-B 27$ heavy chain and $\beta 2 \mathrm{~m}$ occurs also in a synovial tissue and can lead to chronic inflammation. ${ }^{(13-15)}$

Numerous studies have found a close connection between $H L A-B 27$ and diseases of this group. Detection of the carrier state of $H L A-B 27$ is one of modern approaches in preliminary diagnosis and the choice of treatment. Well-timed definition of HLA antigens before the emergence of symptoms allows identifying a risk group for the development of a particular disease. Thus, studying the prevalence of the HLA-B27 gene and features of a clinical aspect of inflammatory joint diseases among the children's population of Yakutia will help to develop effective preventive programs, which, carried out, will reduce the disease burden among children and teenagers. The research objective was to conduct a retrospective study of patients with JA in association with the carriage of the $H L A-B 27$ allele.

\section{Materials and Methods}

Genotyping of HLA-B27 was performed in the laboratory of molecular genetics at Yakut Science Center of Complex Medical Problems. A total of 73 patients (39 boys and 34 girls aged from 1 to 16 years, mean age of $10.28 \pm 4.24$ years) living in Yakutia with JCA (30 Yakuts and 3 Russians), JAS (15 Yakuts and 1 Russians), JPsA (2 Yakuts), and reactive arthritis (RA) (15 Yakuts and 7 Russians) were examined. Among them, 62(84.9\%) children were of Yakut nationality, and $11(15.1 \%)$ - the Russian nationality. The control group included 85 Yakuts without clinical diagnosis of arthritis. The ethnic origin was considered to the third generation.

For specification of the clinical diagnosis and for the purpose of $H L A-B 27$ identification, we conducted a molecular and genetic analysis of 73 children from 73 families. From each patient, $2 \mathrm{~mL}$ of peripheral blood were drawn into an EDTA tube. Genomic DNA was isolated from the peripheral blood leukocytes using standard phenol-chloroform extraction technique (Maniatis et al., 1982)

Testing for the $H L A-B 27$ allele was performed according to Dominquez et al. (1992) as modified by Steffens-Nakken et al. (1995). Primers are amplifying codons 91-136, E91S (5'GGG TCT CAC ACC CTC CAG AAT-3') and 136AS (5'-CGG CGG TCC AGG AGC T-3') (amplificate length 135 bp). For internal control, the $\beta$-globin gene was genotyped by primers PCO4 (5' - CAA CTT CAT CCA CGT TCA CC-3') and GH20 (5' - GAA GAG CCA AGG ACA GGT AC-3') (amplificate length $268 \mathrm{bp}$ ). All primers described above were synthesized in MNPK Biotekhindustriya. (Moscow, Russia). ${ }^{(16-18)}$

The reaction mixture $(20 \mu \mathrm{L})$ contained : $50 \mathrm{ng}$ of DNA, 0.15-0.9 mmol/1. of primers (MNPK Biotekhindustriya), $200 \mathrm{mmol} / \mathrm{L}$ of each nucleotide triphosphate (NTP) (Sileks, Russia), 2 units of DNA polymerase (Sileks, Russia), 10×PCR buffer $(500 \mathrm{mmol} / \mathrm{l} \mathrm{KCl}, 100 \mathrm{mmol} / \mathrm{l}$. Tris- $\mathrm{HCl}(\mathrm{pH}=8.3)$, gelatin $1 \mathrm{~g} / 1,11 \mathrm{mmol} / 1 \mathrm{MgCl}_{2}$ ) (Sileks, Russia).

PCR was conducted in the MJ Mini Gradient Thermal Cycler (BioRad). The DNA was amplified using the following thermocycling steps: $94^{\circ} \mathrm{C}$ for $100 \mathrm{sec}, 94^{\circ} \mathrm{C}$ for $1 \mathrm{~min}, 57^{\circ} \mathrm{C}$ for $1 \mathrm{~min}, 30$ cycles of $72^{\circ} \mathrm{C}$ for $2 \mathrm{~min}, 72^{\circ} \mathrm{C}$ for $10 \mathrm{~min}$.

PCR products were analyzed on $2 \%$ agarose gels after staining with ethidium bromide and were visualized using a UV transilluminator (Vilber Lourmat, France) (Fig.1).

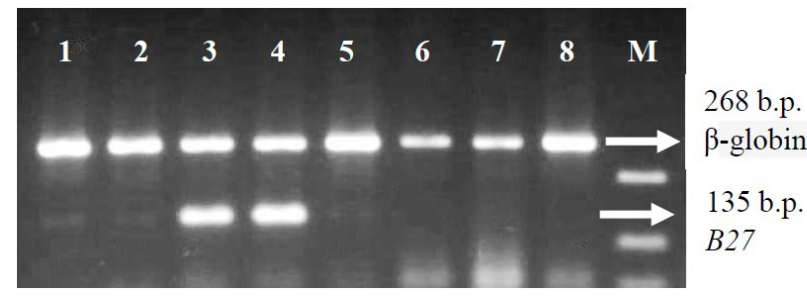

Fig.1. Electrophoretogram of the PCR products on a $2 \%$ agarose gel.

Statistical analysis was performed using the Statistica 8.0 software package (StatSoft Inc, USA). Differences in the HLA-B27 allele distribution between the two groups were assessed by $\chi^{2}$ - test with 1 degree of freedom (df) or Fisher's exact test. Odds ratios (ORs) and 95\% confidence intervals (CIs) were calculated. A probability value of $P<0.05$ was considered statistically significant.

\section{Results and Discussion}

According to the genotyping results, in 30 of 73 examined samples an association was found between the $H L A-B 27$ allele carriage and JA. We did not find the HLA-B27 allele in 43 patients with JA. The $H L A-B 27$ allele was diagnosed in 24 (38.7\%) Yakuts and 6(54.5\%) ethnic Russians. For further analysis, all patients (Yakuts, Russians) were divided into diagnosis-related groups. Diagnoses of JAS $(n=10)$ and JCA $(n=9)$ prevailed in Yakuts. In the Russian children, RA was more common $(n=4)$.

For comparison, population sample of healthy Yakuts (without JA and family burden for JA) $(n=85)$ was tested. All DNA samples of population sampling were genotyped for the carriage of the HLA-B27 allele. The frequency of the HLA-B27 allele varies widely across populations, from $0.4 \%$ to $39.6 \%$ the lowest frequency in Japanese from the southern regions of 
Japan, the highest frequency in Koryaks from settlements of the Koryak Autonomous Area (Tymlat and Voyampolka). ${ }^{(19)}$ In populations of Europe, the frequency of the $H L A-B 27$ allele is from $4 \%$ to $8 \%$, in ethnic Russians - $10.4 \%{ }^{(20,21)}$ Studies conducted on different populations of the world have shown that the highest and lowest frequency of $H L A-B 27$ is detected in populations belonging to the Mongoloid race (Fig.2). In our research, in population sampling of Yakuts, the frequency of the $H L A-B 27$ allele was $33 \%$. It can possibly be defined by similarity of profiles of the HLA system and ethnogenetic bases of populations of the Arctic mongoloids and Yakuts. The distribution of Yakut patients by gender showed an insignificant prevalence of male patients (54.8\%). In sampling of Russians, this distribution appeared approximately identical, probably because of a small number of patients $(n=11)$.

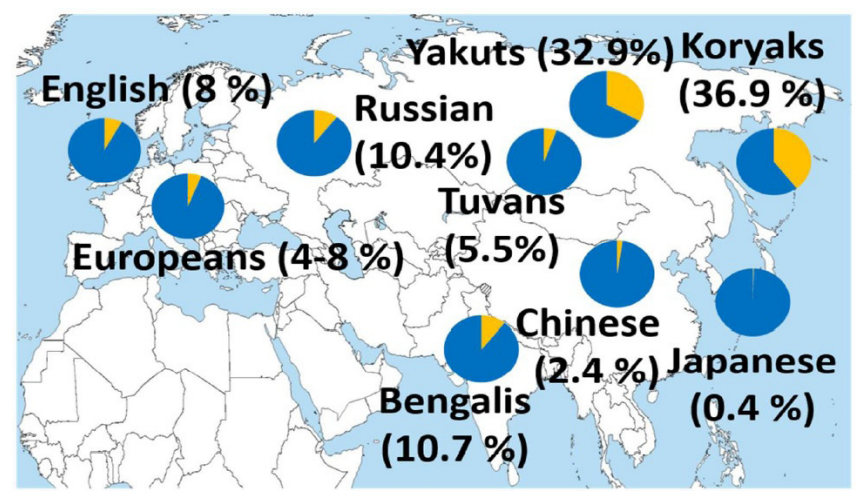

Fig. 2. The frequency of the HLA-B27 allele in the different populations.

While comparing the frequency of the HLA-B27 allele in the group of patients (JA and RA) of the Yakut nationality $(38.7 \%)$ with population sampling of Yakuts $(32.9 \%)$, an association with the $H L A-B 27$ allele carriage was not found (Table 1). A similar analysis for the Russian patients was impossible due to the lack of comparative control. The Yakut patients were divided into diagnosis-related groups: JAS $(\mathrm{n}=15), \operatorname{JCA}(\mathrm{n}=30), \operatorname{JPs} \mathrm{(n}=2)$ and $\mathrm{RA}(\mathrm{n}=15)$. A comparison of the frequencies of the HLA-B27 allele among the Yakut patient groups and the control group found a statistically significant association with JAS (Table 1).

Table 1.

The frequency of the HLA-B27 allele in the studied groups of Yakut patients

\begin{tabular}{|l|c|c|c|c|}
\hline № & Group & $\begin{array}{c}H L A-B 27 \\
\mathrm{n}(\%)\end{array}$ & OR (95\% CI) & $P$-value \\
\hline 1 & JAS $(\mathrm{n}=15)$ & $10(66.7)$ & $4.071(1.270-13.052)$ & 0.0182 \\
\hline 2 & JCA $(\mathrm{n}=30)$ & $9(30)$ & $0.872(0.354-2.151)$ & 0.7670 \\
\hline 3 & JPsA $(\mathrm{n}=2)$ & $0(0)$ & 0.000 & 1.0000 \\
\hline 4 & RA $(\mathrm{n}=15)$ & $5(33.3)$ & $1.018(3.217-3.263)$ & 0.9762 \\
\hline \multicolumn{2}{|l|}{ Total $(\mathrm{n}=62)$} & $24(38.7)$ & $1.286(0.650-2.544)$ & 0.4704 \\
\hline $\begin{array}{l}\text { Control group } \\
\text { (Yakuts) (n=85) }\end{array}$ & $28(32.9)$ & - & - \\
\hline
\end{tabular}

We found also a statistically significant association with the carriage of the HLA-B27 allele in the male subgroup $(\mathrm{OR}=5.6471$, 95\% CI: 1.3474-23.6676; $P=0.018$ ) (Table 2). Thus, the carriage of the $H L A-B 27$ allele in Yakut males increases the risk of JAS by 5.6 times.

Table 2.

The frequency of the HLA-B27 allele in the studied groups of Yakut patients depending on gender

\begin{tabular}{|c|c|c|c|c|c|c|c|c|c|}
\hline \multirow[b]{2}{*}{ № } & \multirow[b]{2}{*}{ 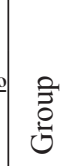 } & \multicolumn{4}{|c|}{ Male } & \multicolumn{4}{|c|}{ Female } \\
\hline & & $\mathrm{n}$ & $\begin{array}{l}\text { HLA- } \\
\text { B27 } \\
\text { n (\%) }\end{array}$ & $\begin{array}{c}\text { OR } \\
(95 \% \mathrm{CI})\end{array}$ & $P$ & $\mathrm{n}$ & $\mid \begin{array}{c}\text { HLA- } \\
\text { B27 } \\
\text { n (\%) }\end{array}$ & $\begin{array}{c}\text { OR } \\
(95 \% \mathrm{CI})\end{array}$ & $P$ \\
\hline 1 & JAS & 12 & $\begin{array}{c}9 \\
(75)\end{array}$ & $\begin{array}{c}5.647 \\
(1.347-23.668)\end{array}$ & 0.018 & 3 & $\left(\begin{array}{c}1 \\
(33.3)\end{array}\right.$ & $\begin{array}{c}1.136 \\
(0.093-13.886)\end{array}$ & 0.920 \\
\hline 2 & $\mathrm{JCA} \mid$ & 12 & $\begin{array}{c}4 \\
(33.3)\end{array} \mid$ & $\begin{array}{c}0.941 \\
(0.247-3.582)\end{array}$ & 0.930 & 18 & $\begin{array}{c}5 \\
(27.8)\end{array}$ & $\begin{array}{c}0.874 \\
(0.250-3.056)\end{array}$ & 0.833 \\
\hline 3 & RA & 9 & $\left(\begin{array}{c}3 \\
(33.3)\end{array}\right.$ & $\begin{array}{c}0.941 \\
(0.209-4.242)\end{array}$ & 0.938 & 6 & $\left(\begin{array}{c}2 \\
(33.3)\end{array}\right.$ & $\begin{array}{c}1.1364 \\
(0.180-7.152)\end{array}$ & 0.892 \\
\hline 4 & JPsA & 1 & 0 & 0 & 1 & 1 & 0 & 0 & 1 \\
\hline & Total & 34 & $\begin{array}{c}16 \\
(47.1)\end{array}$ & $\begin{array}{c}1.6732 \\
(0.684-4.092)\end{array}$ & 0.260 & 28 & $\begin{array}{c}8 \\
(28.6)\end{array}$ & $\begin{array}{c}0.909 \\
(0.308-2.688)\end{array}$ & 0.863 \\
\hline & $\begin{array}{l}\text { Control } \\
\text { roup } \\
n=85)\end{array}$ & 49 & $\begin{array}{c}17 \\
(34.7)\end{array}$ & - & - & 3 & $\begin{array}{c}11 \\
(30.6)\end{array}$ & - & - \\
\hline
\end{tabular}

In conclusion, the population frequency of the $H L A-B 27$ allele in Yakuts was $32.9 \%$. In the Yakut population, the association between the carriage of the $H L A-B 27$ allele and JAS was not found, which might be due to a highly heterogeneous sample of patients. The carriage of the HLA-B27 allele in Yakut females did not increase the risk of JAS development, whereas in male Yakuts this risk increased by 5.6 times.

\section{Competing Interests} interests.

The authors declare that they have no competing

\section{References}

1. Bochkov N.P. Human genetics (heredity and pathology). M.: Meditsina; 1978.[in Russian].

2. Murphy EA, Chase GA. Principles of Genetic Counseling. Yearbook Medical Publishers, Chicago; 1975

3. Benevolenskaya L, Myakotkin V, Ondrashik M, Gemer B. Clinical and genetic aspects of rheumatic diseases. M.: Meditsina; 1989. [in Russian].

4. Zolobova ES, Yasdovsky VV, Voronin AV, Boldyreva MP. [Immunogenetic features of juvenile rheumatoid arthritis]. Rheumatology Science and Practice. 2007;45(5):66-73. [Article in Russian].

5. Thomas GP, Brown MA. Genetics and genomics of ankylosing spondylitis. Immunol Rev. 2010;233(1):162-80. doi: $10.1111 /$ j.0105-2896.2009.00852.x. 
6. Morling N, Friis J, Fugger L, Georgsen J, Heilmann C, Pedersen FK, et al. DNA polymorphism of HLA class II genes in pauciarticular juvenile rheumatoid arthritis. Tissue Antigens. 1991;38(1):16-23.

7. Wordsworth P. Progress in the immunogenetics of rheumatoid arthritis. Hosp Pract (Off Ed). 1995;30(4):77-81.

8. Nasonov EL. Genetically engineered biological medications in the treatment of rheumatoid arthritis. M.: IMA- PRESS; 2013. [in Russian].

9. Nasonov EL, Denisov LN, Stanislav ML. [Interleukin-17 is a new target for anti-cytokine therapy of immune inflammatory rheumatic diseases]. Rheumatology Science and Practice. 2013;51(5):545-552. [Article in Russian].

10. Szegezdi E, Logue SE, Gorman AM, Samali A. Mediators of endoplasmic reticulum stress-induced apoptosis. EMBO Rep. 2006;7(9):880-5.

11. Kitamura M. Endoplasmic reticulum stress and unfolded protein response in renal pathophysiology: Janus faces. Am J Physiol Renal Physiol. 2008;295(2):F323-34. doi: 10.1152/ ajprenal.00050.2008.

12. DeLay ML, Turner MJ, Klenk EI, Smith JA, Sowders DP, Colbert RA. HLA-B27 misfolding and the unfolded protein response augment interleukin- 23 production and are associated with Th17 activation in transgenic rats. Arthritis Rheum. 2009;60(9):2633-43. doi: 10.1002/art.24763.

13. Schaeverbeke T, Truchetet ME, Richez C. Gut metagenome and spondyloarthritis. Joint Bone Spine. 2013;80(4):349-52. doi: 10.1016/j.jbspin.2013.02.005.
14. Sherlock JP, Cua DJ. Interleukin-23: a promising therapeutic target in seronegative spondyloarthropathy. Curr Opin Pharmacol. 2013;13(3):445-8. doi: 10.1016/j.coph.2013.03.002.

15. Colbert RA, Tran TM, Layh-Schmitt G. HLA-B27 misfolding and ankylosing spondylitis. Mol Immunol. 2014;57(1):44-51. doi: 10.1016/j.molimm.2013.07.013.

16. Steffens-Nakken HM, Zwart G, van den Bergh FA. Validation of allele-specific polymerase chain reaction for DNA typing of HLA-B27. Clin Chem. 1995;41(5):687-92.

17. Dominguez O, Coto E, Martinez-Naves E, Choo SY, López-Larrea C. Molecular typing of HLA-B27 alleles. Immunogenetics. 1992;36(5):277-82.

18. Bon MA, van Oeveren-Dybicz A, van den Bergh FA. Genotyping of HLA-B27 by real-time PCR without hybridization probes. Clin Chem. 2000;46(7):1000-2.

19. Fefelova VV, Khamnagadaev II., Polikarpov LS. [HLA-B27 antigen and spondyloarthropathies in Arctic Mongoloids]. Bulletin of the SB RAMS] 2010;30(6):136-139. [Article in Russian].

20. Brewerton DA, Hart FD, Nicholls A, Caffrey M, James DC, Sturrock RD. Ankylosing spondylitis and HL-A 27. Lancet. 1973;1(7809):904-7.

21. Konenkov VI, Golovanova OV, Prokof'ev VF, Shevchenko $\mathrm{AV}$, Zonova EV, Korolev MA, et al. [Distribution of allelic variants of promotor sites of cytokine genes and endothelial growth factor gene among healthy subjects and patients with rheumatoid arthritis in a Russian Europeoid population]. Vestn Ross Akad Med Nauk. 2010;(9):9-14. [Article in Russian]. 